Issues in Information Systems

Volume 18, Issue 4, pp. 65-69, 2017

\title{
EMBRACING THE DIVERSE ENVIRONMENT IN THE WORK PLACE
}

\author{
Brian Gutierrez, Minot State University, brian.gutierrez@minotstateu.edu \\ Deanna Klein, Minot State University, deanna.klein@minotstateu.edu
}

\begin{abstract}
The present work place provides an eclectic environment that has less to do with usual demographics used to describe an environment such as race or gender, and more to do with age differences. The following research defends the idea that age differences bring different points of views to the work place. Age differences can also affect the way people learn the best, what interests them, the way they communicate, and the best environment that inspires efficiency of the work operation. As a result, suggestions will be made as to how it is important to learn the characteristics of the employees to find the educational and management style that is most fitting for the workplace.
\end{abstract}

Keywords: Generations, Workplace, Culture, Employees, Education

\section{INTRODUCTION}

It is imperative to understand that throughout the paper, each generation is not being stereo typed, but rather being analyzed with the idea that it is reasonable to say that people are shaped by their experiences and the environment they were brought up in. Someone who grows up in a time of hardship is molded by his or her struggle and his or her views may be shaped around that experience. Experiences turn into views and views can become a part of how the employee engages in the work place. Therefore, keep in mind that the following is an analysis on learning and how it applies to the diverse environment that makes up the modern work place, as it is an interesting environment indeed.

\section{GENERATIONAL DIFFERENCES IN THE WORK PLACE}

Before we can learn to manage the generational differences, it is important to be able to recognize each generation along with its characteristics. The different generations that will be analyzed are the Veterans, Baby-boomers, Generation X, and Millennials. To be able to understand the general differences, the way each generation responds to the different environment and what engages them to work at the highest and most efficient level will be reviewed.

\section{Veterans (Silent Generation)/Traditionalists}

The Veterans, also known as the "silent generation" or traditionalists, are those in the work force that have had no other option but to put retirement on hold because of financial circumstances. The youngest of this generation are in their late 60s and 70s (Thompson, 2011). Although not common, the Veteran generation can still be found in the work place. There are a few historical events that have helped shape the Veteran generation. This generation lived with little to no controversy and is more likely to cling to tradition (Patterson, 2007). By clinging to tradition, this generation may be reluctant to change in the work place.

The Veteran generation was born in between the years of 1927 to 1945. The Veteran generation may also be known as the "silent generation" because they have been known to experience hardship and adversity. The Veteran generation witnessed; the Great Depression, WWII, Korean War, and shaped the Veteran culture. Their work values involve loyalty, recognition, hierarchy, and resistance to change (Fogg, 2008). The generational work values can allow the workers of this generation to build a level of comfort and value for the job. The Veteran generation are loyal, hardworking, financially conservative, and faithful to institutions (Arnold \& Williams, 2008). The pride and 


\title{
Issues in Information Systems
}

\author{
Volume 18, Issue 4, pp. 65-69, 2017
}

high level of loyalty can create an opportunity of a long lasting employment relationship with this generation, which can be a benefit to the company.

In addition, the Veteran generation has experienced war and has witness civil rights and feminist movements. According to Patterson (2007), this generation is more inclined to believe in the status quo and willing to accept change gradually which is difficult in this time of rapid changes due to technology. This would explain where the Veteran generation is also considered the "silent generation." Following status quo, the Veteran generation is not one to speak up, which can transfer in the work place as having high respect for their leaders, and a respect for their role in the big picture of operations, and waiting for their turn to climb up the corporate ladder.

\section{Baby Boomers}

The Baby Boomers include the part of the workers that were born between the years 1946 to 1964 . By being a product of the Veteran generation, Baby boomers share similar traits in the work place. Baby Boomers are loyal employees with a strong sense of duty (Hahn, 2011). This generation is known for the sense of loyalty and work ethic in the workplace.

Baby Boomers grew up during the prosperity that came after World War II. Baby Boomers are influenced by television visual news stories, Civil Rights movements, the Vietnam War, the landing of the man on the moon, and bring a positive attitude in the workplace (Hahn, 2011). This generation may have the responsibility of caring for both their children and their parents. Baby Boomers are an offspring of "permissive" parenting and consistent messages of unlimited possibilities for achievement resulted in an individualistic environment (Patterson, 2007). Baby Boomers were advised to work for a better lifestyle than the one their parents had. With this advice, Baby Boomers bring a high level of commitment to the work place. This generation also has a higher level of education than the previous generation. Education allowed for an opportunity for a better job, and a better job opened the door to a better lifestyle.

\section{Generation X}

Generation X includes those born within the mid-1960s and 1980s. This generation has more exposure to technological advancements. This generation's population is not as large compared to the previous and the following generation. Generation X experience self-centered parents who put more value to their careers rather than families; therefore, this generation has put more value on family than a career (Patterson, 2007). Generation X are raised by a more conservative generation. Furthermore, Generation $\mathrm{X}$ is more exposed to technology than the other generations, giving the generation an upper hand in the modern work place.

Generation $\mathrm{X}$ does not have a high level of loyalty. This generation does not have the same expectations for performance in their work, and build portable careers and appear ready to change employers as attractive opportunities and challenges arise (Patterson, 2007). To be able to manage Generation X it is imperative to make the work environment appealing, knowing that these workers are known for challenging themselves and not being afraid to pursue careers in other companies.

The low level of value Generation $\mathrm{X}$ has for their job could be a flag for management considering the risk of having to replace the employees hired. Furthermore, at any sign of change being introduced where the generational correspondent does not agree, there is always the unfortunate risk of losing the employee. This generation is not influenced by historical events, like the ones that came before it. Cultural influences of this generation include the fall of the Soviet Union, women's liberation movement, MTV, Internet, home computers, and video games (Fogg 2008). Although tech-savvy, the generation is independent and is less influenced by the benefits and securities that the job may bring to them. 
Issues in Information Systems

Volume 18, Issue 4, pp. 65-69, 2017

\section{Millennials}

Generation Y, or further known as Millennials, includes those born between 1980s to late 1990s. This is the rise of instant communication, which has revolutionized communication in the work place. Being raised self-directed, more incline to accept diversity, Millennials accept multiculturalism. Furthermore, growing up, Millennials spent after school participating in multiple school activities (Hahn, 2011). This generation has been multi-tasking from a young age bringing multiple attributes to the work place. Furthermore, they are not afraid to balance multiple activities and offer flexibility in the workplace.

Millennials are deeply affected by the idea of instant communication. Social media has revolutionized the way people communicate. The Internet era, September 11 terrorist attacks, cellphones, and social media have shaped the millennial generation (Fogg, 2008). This era believes in staying involved; furthermore, being able to stay involved and maintains a healthy lifestyle. Millennials defend that it should not matter where or when the work gets done as long as it is accomplished (Thompson, 2011). Procrastination can be a downfall of this generation, or an asset, depending on what angle you see it from. Millennials are hard working in their own way, things get taken care of, but at the time and pace of the person it is assigned to.

This generation grew up in a time of violence witnessing historical events such as the Gulf War, the Columbine Shooting, the Oklahoma City bombing, the initiation on the global war on terrorism, and September 11 (Hahn, 2011).

\section{THE MODERN WORKPLACE}

After identifying the four different generations and defining the characteristics they each bring to the work place, it is vital to identify the work environment they are put into. The effects of the work environment may affect each generation in the sense of whether or not they are being put in the right environment to succeed. As management, it is important to find the most efficient and effective way of production. Therefore, it is pivotal to find the right people to put into the proper processes to get the most productivity out of each employee.

\section{The Work Environment}

Author of "Gen busting," Pete Tokar, refers to the number of generations in the work place as a "generational super storm" (Tokar, 2013). Tokar goes further by making a case that having multiple generations in a workplace is a common trend across the US. In an environment where you have employees getting ready for retirement, along with recent college graduates, and a few more in between, there may be different interests from each generation in terms of what they seek to attain from the job. Whether it is a sense of belonging or a passion for what the job entitles, each employee seeks a different interest. Examples may be on how a Veteran/Traditionalist may have respect for loyalty, patience, mission, and respect as Baby boomers put an importance on teamwork, work ethic, getting the job done, and recognition. Generation X seeks ongoing learning, feedback and informality. Millennials, however, seek achievement, structure, and work values (Mullan, 2008). Therefore, constructing a work environment that can withhold the different amount of views in a workplace can be a difficult task for management. Differences in the views of each employee can directly affect productivity in the workplace (Mullan, 2008). When a group of people disagree, or don't see eye-to-eye, conflict can arise. Conflict in the work place can distract workers' productivity.

As an example, Joyce Hahn (2011) takes a look into the nurse work force and defines the different types of nurses that may be involved in the industry. There are nurses who are preparing for retirement, but there are also new nursing graduates who have been trained in innovative nursing programs. Looking at this from a broad perspective it is reasonable to assume that other industries may be experiencing the same trend. New college graduates have undergone different types of teaching methods in their classes. Furthermore, the teaching methods have been tailored and modernized; therefore, learning techniques have change. The way people receive information and put it into practice may be different form previous generations. 
Issues in Information Systems

Volume 18, Issue 4, pp. 65-69, 2017

Table 1. Current population size within each generation of employees from a Midwestern, multi-location bank.

\begin{tabular}{|l|c|l|l|}
\hline \multicolumn{1}{|c|}{ Generation Name } & Midwestern (YE 2016) & Communication Style & Work/Life Balance \\
\hline $\begin{array}{l}\text { Traditionalists (born 1945 } \\
\text { and earlier) }\end{array}$ & 0 & $\begin{array}{l}\text { Discrete, } \\
\text { Present your story in a } \\
\text { formal, logical manner, } \\
\text { Show respect }\end{array}$ & $\begin{array}{l}\text { "Ne'er the two shall } \\
\text { meet" } \\
\text { Keep them separate }\end{array}$ \\
\hline $\begin{array}{l}\text { Baby Boomers (born } \\
1946 \text { to 1964) }\end{array}$ & $115(21 \%)$ & $\begin{array}{l}\text { Diplomatic } \\
\text { Prefer in person } \\
\text { Speak openly - direct } \\
\text { style }\end{array}$ & $\begin{array}{l}\text { No balance } \\
\text { "Live to work" }\end{array}$ \\
\hline $\begin{array}{l}\text { Generation X (born 1 } \\
\text { tool1965 to 1976) }\end{array}$ & $110(20 \%)$ & $\begin{array}{l}\text { Blunt/Direct } \\
\text { Immediate } \\
\text { Use straight talk, present } \\
\text { facts } \\
\text { Use email as \# 1 tool }\end{array}$ & $\begin{array}{l}\text { Work to live, not live to } \\
\text { work }\end{array}$ \\
\hline $\begin{array}{l}\text { Millennials - Gen Y } \\
\text { (born 1977 to 1995) }\end{array}$ & $307(55 \%)$ & $\begin{array}{l}\text { Use positive, respectful, } \\
\text { motivational, electronic } \\
\text { communication style (Cell } \\
\text { phones, email, IM, Text) }\end{array}$ & $\begin{array}{l}\text { "Work to live" } \\
\text { Balance is important } \\
\text { They value their lifestyle } \\
\text { over upward mobility }\end{array}$ \\
\hline $\begin{array}{l}\text { iGen-Gen Z (born 1996 } \\
\text { and after) }\end{array}$ & $22(4 \%)$ & $\begin{array}{l}\text { Electronic (imagery) } \\
\text { Short messages - } \\
\text { mothering too lengthy }\end{array}$ & $\begin{array}{l}\text { "Work-life balance" } \\
\text { Increased flexibility } \\
\text { Rapid advancement }\end{array}$ \\
\hline
\end{tabular}

With the information provided, it is clear which generation makes up the majority of the population. The population synapsis can give a picture on what the ideal management environment that management should create to help generations to co-exist. As the table reflects, the majority of the population at the organization is the Millennials, followed by Baby Boomers, then Gen X, and surprisingly Gen Z, a generation similar to that of Millennials. The management should reflect an environment that tapers according to the different generations in the organization. Therefore, the environment should reflect purpose; provide technological innovation, with strong structure, for the Millennials, along with an environment that inspires learning and independence, and opportunities for mentoring, for Generation X, but also provide positive feedback, and employee recognition for Baby boomers. Furthermore, it is recommended that each generation be considered for jobs that reflect their ideal environment. For example, jobs that reflect independence and projects may be beneficial for Generation X, as jobs that offer opportunities to make an impact and make a positive difference may be for Millennials. Paring each generation up with the ideal job position is more beneficial that sending each individual through a pre-set career assembly line. By putting each employee in the right employment position, they can exhale and triumph, and feel passionate and inspired to work efficiently.

\section{CONCLUSION}

In a world where there is always room for innovation and rapid change in technology, it is important form management now more than ever to understand the importance of the duty they have to the organization.

By creating a balance between tradition and innovation in the work place, all generations can coexist. Furthermore, if the industry is changing rapidly, it is important for the company to invite innovation, which can allow opportunity to have employees with the skill set to help bring innovation to the work place. Management should sway itself from the idea of what the employee can do for the company, and ask itself what resources and benefits the organization can provide for the employees to succeed. In order to set up the right environment - communication, flexibility and understanding, should be invited into the work place. Establishing different forms of communication in the work 


\section{Issues in Information Systems}

Volume 18, Issue 4, pp. 65-69, 2017

place can help each employee use what is the most comfortable for to them to increase efficiency. Flexibility and understanding allows for all employees of all generations to coexist. In order for all generations to exist, it is pivotal to be accepting of different opinions, and create an adaptive environment. An adaptive environment emphasizes on tailoring the work place to the employee by creating good incentives and compensation, along with growth and development for all generations to coexist.

\section{REFERENCES}

Arnold, K., \& Williams, K. (2008). Playbook: Dealing with Generational Crosstalk. Parks \& Recreation, 43(11), 18-19.

Fogg, P. (2008, July 18). When Generations Collide. Chronicle of Higher Education. pp. B18-B20.

Hahn, J. A. (2011). Managing Multiple Generations: Scenarios from the Workplace. Nursing Forum, 46(3), 119127. doi:10.1111/j.1744-6198.2011.00223.x

Mullan, E. (2008). The Generational Divide: World of Work Survey Encourages Collaboration. Econtent, 31(9), 1617.

Patterson, C. K. (2007). The Impact of Generational Diversity in the Workplace. Diversity Factor, 15(3), 17-22.

Thompson, M. W. (2011). Prevention in a Multigenerational Workplace. Professional Safety, 56(5), 32-35.

Tokar, P. (2013). GEN busting. Economic Development Journal, 12(1), 41-46. 